Nineteenth Scientific Meeting-Ninth Scottish Meeting

Joint Meeting with the Association of Scientific Workers and the Workers Educational Association

\author{
West of Scotland Coldege of Domestic Solence, Glasgow, \\ MARCH 11TH, 1944
}

\title{
SCIENCE AND POST-WAR RELIEF
}

\author{
Chairman, Professor D. Murray Lyon
}

Professor D. Murray Lyon (Clinical Medicine Department, Royal Infirmary, Edinburgh): The subject of the meeting is one of supreme importance. These are days of planning, and everyone is turning his attention to the future. In many cases plans come out of the air without experience. In the case of starving Europe, however, we have experience arising out of the last war. Before we can face the problem it is just as well to have it clearly stated, and today our speakers will put before us what the problems are, and what will be required in the post-war period.

\section{Some Effects of Inanition and their Treatment}

\section{Dr. H. E. Magee (Ministry of Health, Whitehall, London, S.W.1)}

The peoples of Europe who will require relief will be suffering from want of food, from inanition. We are all too apt these days to imagine that relief parties will be faced with a host of well defined deficiency conditions and that treatment will consist simply of the prescription of doses of appropriate, concentrated nutrients, especially vitamins. It cannot be denied that we are at present affected in some degree by a vitamin complex. People will want food in the first instance. There may be very many whose condition will be such that the giving of food will require considerable care and discretion. It therefore seems to me highly desirable that relief parties should bear in mind the physiological and pathological effects of deprivation of food.

I propose to remind you briefly of the classical effects of inanition and then to put before you a review of some recent reports of observations made on starving people, the signs and symptoms they showed, the treatment adopted and its outcome. I do not claim that this paper is in any sense exhaustive. I bring this subject before you to emphasize its importance, and hope that someone with sufficient time will make a complete study of it so that relief parties may be the better equipped for their work. I am convinced that without knowledge of this subject they would save fewer lives than they might otherwise do. The trend of papers and correspondence in the press, medical and lay, makes one feel that the subject has so far received scant attention.

\section{Effects of Inanition}

Starvation to the point of death has been studied only in animals. Professional fasters have lived for as long as 50 days on water only but, 
for obvious reasons, the final stage of exhaustion was never reached. Consequently, for the terminal stages of starvation we have to rely on data from animals, but, as we shall see later, some recent reports add considerably to our knowledge of the terminal stages of inanition in man.

Knowledge of the effects on man has been derived mainly from the observations of Benedict (1915) on his famous fasting man Levanzin. His is the most comprehensive series of observations we possess but others, for instance Catheart, Munk, Zuntz, Voit and Tigerstedt, have also made observations on professional fasters. The names of Cetti, Succi and Breithaupt have honoured places in text books of physiology. An account of these observations will be found in the book by Lusk (1928).

A steady loss of weight occurs affecting most the digestive organs, skin and muscles, least, the central nervous system, organs of special sense, skeleton, endocrine and reproductive organs and, intermediately, the heart, lungs and other tissues. The losses of body substance are therefore in conformity with the urge of nature to preserve the life of the individual and the continuation of the species. The water content of the body is increased; water evidently replaces fat in tissues. In 31 days of fasting, Levanzin lost 20 per cent. of his weight.

Levanzin's basal metabolic rate fell from 1846 Calories daily before the fast to 1248, which was the lowest reached, on the 22nd day. Muscular strength was not, however, appreciably diminished, perhaps because his efforts on the work machine improved with practice. Benedict reports that there was "no lasting effect of the fast on muscular strength or neural activity". Levanzin's temperature fell to about $36^{\circ} \mathrm{C}$. at the end of the fast. In animals before death there is a marked fall of temperature.

The blood volume falls but the proportion to the bodyweight remains fairly constant. The gross composition is not very much altered. The red blood cell count remains about the same but the white blood cells are reduced slightly. Blood pressure falls in man and animals, and the pulse slows. Arrhythmia develops in animals at the end. The respiration rate is not much affected.

From detailed observations on animals it appears that the intestinal epithelium atrophies, the columnar cells become flattened, the rate of absorption is lowered and assimilation is interfered with (cf. Magee, 1930). The sugar tolerance curve is high and prolonged; glycosuria occurs even after starch feeding, resulting in the so called hunger diabetes. Goettsch, Lyttle, Grim and Dunbar (1943) have recently shown that administration of amino-acids after a period of low protein feeding results in their accumulation in the blood. The metabolic functions are, thercfore, evidently impaired. The permeability of the intestinal epithelium is increased and its protective function, therefore, decreased so that there is greater tendency to absorption of toxins. Intestinal ulcers develop, especially in the large intestine. In many recent cases of death from starvation, such ulcers have been seen post mortem. Resistance to disease is much diminished. For instance, smallpox vaccinations become positive with people who before starvation gave negative reactions.

Gastric secretion continues throughout the fast but the amount of hydrochloric acid and the digestive activity diminish. Little is known for certain about pancreatic and intestinal juices. 
The evidence so far as it goes, therefore, indicates that complete starvation, besides causing the more obvious and predictable effects observed in professional fasters, e.g., loss in weight and lowering of the basal metabolic rate, has detrimental effects also on the digestive, absorptive and metabolic functions, and lowers the resistance to disease.

\section{Effects of Partial Starvation}

Probably very few of the people to be relieved will be suffering from complete deprivation of food. Most will have been eating some food, but the diets will have been ill balanced. It would, I think, be futile to try to picture the kinds of diets which people have been subsisting on with a view to visualizing the kind of deficiencies one is likely to meet. This could doubtless be done if the complete facts of the food situation in occupied countries were accurately known and if it were possible to make them public. I think, however, I can best serve the purpose of this paper by considering published and other material which has recently come to hand. I shall select for consideration the most prominent signs and symptoms that have appeared in these reports, the source of some of which cannot at present be disclosed.

Hunger Oedema is caused, according to Jiménez Díaz, Lorente, Marina, Ortiz de Landázuri and Roda (1942) by a diet low in calories and containing very little animal protein. Dumont and Lambrechts (1942) have shown that deficiencies of vitamins $A, B$ and $C$ have nothing to do with its aetiology. Berning (1942) states that hunger oedema occurs in soldiers when food is inadequate, physical demands are great and the weather is bad. Perakis and Bakalos (1943) attribute the state to deficiency of protein combined with the consumption of relatively large amounts of salt and water. One of their cases, for instance, suddenly developed oedema after a meal of spinach with liberal helpings of salt and water. These observers obtained good results by feeding the patients on fat but they thought that the effect may have been due to the protein sparing effects of fat. R. B. Hawes (personal communication) has seen hunger oedema precipitated in starving Malayans by eating salt meat or fish.

Before the oedema develops the following are observed: easy fatigue, lowered capacity for work, loss of sexual desire, headache, pains in the legs, intense hunger, craving for carbohydrates and salt, diarrhoea and suppression of urine.

The oedema begins in the abdomen and legs and then spreads over the body; in bad cases there may be ascites but there are no pericardial or pleural effusions. The skin is shiny and sensitive. The blood pressure is low, the pulse slow, the kidneys function normally and the urine is free from albumin. The tendon reflexes disappear, control of the bladder and rectum is lost and there are neuralgic pains and tremors; ataxia and paraesthesia develop, and sometimes keratitis.

According to recent observations in Europe, children do not develop typical oedema but are pale and fat, with doughlike appearance; they become thin on re-feeding.

Gastro-intestinal Troubles. These are the most serious symptoms of all and recovery is relatively infrequent. The tongue is denuded of epithelium and red; the teeth decay, and the mouth and gums are swollen

vor. 3,1945 ] 
and inflamed as in scurvy, but these are only minor features compared with the general condition of the patient. The stomach is dilated and there is profuse watery diarrhoea with as many as 30 motions daily. The stools contain undigested food and sometimes mucus. Severe pain occurs in the stomach and abdomen and there is a burning sensation after food. The frequent urination and diarrhoea cause dehydration and emaciation. Death occurs from the severe diarrhoea coupled with cardiac failure.

Neurological and other Symptoms. Besides those already mentioned, namely, neuralgic pains, tremors, ataxia and paraesthesia, there is frank paralysis before death. The disposition is changed, irritability alternates with depression and there is loss of memory and lack of interest in everything but food. Torpor is profound. - Furunculosis is also very frequent but skin conditions typical of any well defined vitamin deficiency are rare. Pellagra like signs are occasionally seen but rarely the classical signs of other vitamin deficiencies.

The Blood. The proteins are low; values as low as 3 to 4 per cent. have been found. The albumin : globulin ratio is higher than normal at first but later tends to fall. The blood sugar is low, 60 to $90 \mathrm{mg}$. per cent., and the sugar tolerance curve is high and prolonged.

\section{Treatment of Starvation}

This depends naturally on the gravity of the condition. The general rule given by Berning (1942) for presumably mild cases is an easily digested diet of high protein content. He particularly recommends curds, cheese, milk or skimmed milk, and casein with calcium gluconate to improve absorption and correct deficiency of calcium. Perakis and Bakalos (1943) had no animal protein at all to give their patients but they obtained good results, even in children, with the best diet they could get, which consisted daily of $30 \mathrm{~g}$. of olive oil, $90 \mathrm{~g}$. of bread, and $180 \mathrm{~g}$. of pulses. This diet removed also all evidence of pellagra which was the only sign of deficiency disease encountered.

Another doctor divides his cases into 3 groups depending on the gravity of the condition. In the mild group recovery is the rule if treatment is prompt. In the most serious group, showing, for example, advanced hunger oedema or diarrhoea, the mortality is very high. Mild cases respond rapidly to easily digested food, particularly milk, eggs, fresh fruit, meat and cereals. These should be given cautiously at first and excessive fat should be avoided to obviate diarrhoea. After about 2 weeks the patients should be able to take ordinary food. For men, a diet supplying up to 4500 Calories a day should be given; food should be eaten 4 times daily. Absolute rest for the first 2 weeks is essential.

Intermediate cases require hospital treatment and good nursing. They should be fed very cautiously on milk and dairy products, avoiding excess of fat. Meat, fruit, cheese, cereals and vitamin concentrates may be given later. The impaired digestion requires pepsin and hydrochloric acid; stimulants such as strychnine may also be required. Diuretics should be given for oedema. Salyrgan (mersalyl of the B.P.), which is a powerful diuretic, is dangerous and should not be given.

At present there is apparently very little hope for serious cases, that is those that have particularly severe diarrhoea. Failure to obtain good 
results may have been due to lack of proper facilities for treatment: hospitals, warmth, good food and good nursing. These cases must have hospital treatment and good nursing if they are to have any chance at all. They should be fed on small quantities of food about 6 times daily, milk, gruels, lean meat, very little fat, with pepsin and hydrochloric acid, and stimulants when required. Frequent intravenous injections of glucose should be given. Opium and potassium permanganate are useful for the diarrhoea.

In mild cases prognosis is good for all ages except the very old. In intermediate cases it is good for those aged 20 to 40 years, bad for the very young and old. In serious cases it is bad for all ages but those aged 20 to 40 have the best chance; for the others it is almost hopeless. Women seem to have better chances of recovery than men.

The treatment for mild and intermediate cases is straightforward, good food, warmth, hospital nursing and rest. The cases with severe diarrhoea are the most likely to succumb. According to the doctor quoted above, most of these people evidently die because they have lost the power of digesting, absorbing and assimilating food on account of atrophy of the digestive organs and absorbing epithelium, and of damage to metabolic functions. Food by mouth is useless to them and the only hope of their recovery would seem to be in the re-establishment of the normal functional activity of the digestive and absorptive organs and of metabolism. To do this the vicious circle has to be broken. The use of protein hydrolysates seems to offer a chance of doing this. These preparations have been given intravenously with striking success for the past 4 to 5 years in the treatment of inanition arising from pathological causes, e.g., oesophageal stricture, cancer of the stomach, intractable diarrhoea and vomiting. This line of treatment was started in the United States (Elman and Weiner, 1939; Elman, 1940). In their last report, Elman, Weiner and Bradley (1942) give an account of about 200 cases, many of them suffering from severe inanition, including nutritional oedema and extreme degrees of dehydration. Good effects of the treatment were obtained in almost every case. Negative nitrogen balances were made positive, blood protein rose, weight increased and the general condition improved. These authors use an acid hydrolysate of casein with tryptophane, and cystine or methionine, and glucose in Ringer's solution. They give during 8 hours out of 24 up to $4000 \mathrm{ml}$. fluid by vein, providing 1600 Calories and $80 \mathrm{~g}$. protein. At first, reactions occurred in some cases, with chill and rise of temperature, but by perfection of technique in preparation, such untoward effects have been eliminated. Brunschwig, Clark and Corbin (1942) and Messinger (1943) have had similar results with the same types of patients. Shohl (1943) successfully treated 20 infants, suffering severely from intractable diarrhoea and vomiting, by venous and oral administration of similar fluids. The vomiting and diarrhoea ceased, nitrogen balances became positive and dehydration disappeared. It is significant that in many of the above mentioned cases blood transfusions had been previously tried without lasting effects.

I understand that suitable hydrolysates are at present under clinical trial in Great Britain.

voL. 3,1945 ] 
REFERENCES

Benedict, F. G. (1915). Publ. Carneg. Instn, no. 203.

Berning, H. (1942). Dtsch. Militärarzt, 7, 733.

Brunschwig, A., Clark, D. E. and Corbin, N. (1942). Ann. Surg. 115, 1091.

Dumont, L, and Lambrechts, A. (1942). Rev. belge Sci. méll. 14, 21.

Elman, R. (1940). Ann. Surg. 112, 594.

Elman, R. and Weiner, D. O. (1939). J. Amer. med. Ass. 112, 796.

Elman, R., Weiner, D. O. and Bradley, E. (1942). Ann. Sury. 115, 1160.

Goettseh, E., Lyttle, J. D., Grim, W. M. and Dunbar, P. (1943). J. biol. Chem. 151,149 .

Jiménez Diaz, C., Lorente, L., Marina, C., Ortiz de Landázuri, E. and Roda, E. (1942). Rev. clin. esp. 6, 289.

Lusk, G. (1928), The Elements of the Science of Nutrition. 4th ed. Philadelphia: W. B. Saunders Co.

Magee, H. E. (1930). Physiol. Rev. 10, 473.

Messinger, W. J. (1943). Arch. intern. Med. 72, 91.

Perakis, K. and Bakalos, D. (1943). Dtsch. med. Wschr. 69, 746.

Shohl, A. T. (1943). J. clin. Invest. 22, 257.

\section{Discussion}

Sir John Orr (Rowett Research Institute, Bucksburn, Aberdeen): Dr. Magee has dealt with a most important problem. We know that already in Europe there is a great deal of hunger and actual starvation. If the problem were to end there it would not be so difficult, but public health services have broken down, and there will be great danger of the spread of infection all over Europe. Dr. Magee brought out the point that malnutrition would lower the resistance to infection. As we know, all through the ages, hunger and disease have gone together. When you add that perhaps twenty million people will be homeless, the magnitude of the problem becomes evident.

We have got UNRRA with Col. Lehman in charge, making great preparations to relieve Europe. One of the things the people of this country can do is to continue rationing after the war because, although ships may be plentiful, there will be a general shortage of foodstuffs. If we do this, we would be doing no more than other countries have done and are doing for us.

Wheat is the food most easily transported and is the basis of relief feeding. We must send to Europe wheat, fats and dried milk in large quantities. These, supplemented where necessary with vitamin concentrates, will supply most of the necessities to avert starvation allied with epidemic disease.

Dr. A. B. Anderson (Biochemistry Department, Royal Infirmary, Glasgow): Dr. Magee said that there was no visible evidence of vitamin deficiency in the starving peoples. Is this because in the starving man the demand for vitamins is less, so that there is still a deficiency but it does not show in the same clinical forms as in the ordinary patient? I was interested to hear Dr. Magee emphasize the importance of aminoacids. We have been interested in another form of starvation, in severe burns, where the best treatment appears to be intravenous feeding with protein hydrolysates. A large quantity of these protein hydrolysates, which can be made from such common proteins as casein, will probably be required for the hospital treatment of starving people. 
Dr. G. Dunlop (Auchincruive, Ayr): Research workers have all their programmes cut and dried already. Are the Ministry of Health themselves doing anything on this subject.?

Dr. Magee gave the following replies:

To Dr. Anderson: I make no claim that my paper is in any way conclusive, but it is very interesting that no gross deficiency is recorded by any of the people mentioned in my paper, except perhaps pellagra. I suppose it is true to say that if the body has not got any food at all, or very little, vitamins, being catalysts, have no work to do. I do not know whether that is the reason for the non-appearance of vitamin deficiency or not.

Regarding the second point, I welcome the opportunity this paper has given me to stress the possible importance of amino-acid therapy. It seems to me, if all the Americans say is true, that, if we arm our relief parties with supplies of protein hydrolysates for Europe, we shall save more lives than otherwise. Extensive research on these hydrolysates shows that we can give them without danger, and so help to reclaim these unfortunate people to good health.

To Dr. Dunlop: The Ministry of Health is primarily only an administrative and not a research body, though it does take an interest in research.

\section{Nutritional Researches in Vienna after the First World War}

Dr. H. Chick (Division of Nutrition, Lister Institute, London, S.W.1)

Conditions Obtaining in the City of Vienna and in Austria in the Years 1919-22

It is common experience that when modern civilization breaks down under stress of war or other severe calamity, the consequences, the disruption of transport, disorganization of economic life, and shortage of food, are most severely felt in the great cities, which in peace time enjoy a greater degree of luxury than the rural districts. To some extent this is true in our own country at the present time, when those who obtain the produce of a private garden can enjoy a more healthy and varied diet than the city dweller who is more completely dependent on the official supplies.

It was much more desperately true in the city of Vienna after the Great War, with its disastrous ending for the Central Powers. Under the Peace Treaty of St. Germain, this great capital with its two million inhabitants was left supported only by an inadequate countryside composed largely of mountain and forest. The neighbouring states, Italy, Hungary, Czechoslovakia, themselves not too well supplied with food, were hostile and disinclined for any degree of co-operation.

Moreover, there was a marked cleavage, not to say antagonism, between the city and country distriets of Austria. Transport had broken down, food was scarce and the existing supplies were not equitably distributed. In the years following the armistice of 1918 , bread was provided by the Government at a low price from flour imported from the U.S.A. Sugar, fats and cheese were rationed but not often available, meat was voL. 3,1945 ] 
scarce and dear, tea and coffee unobtainable. There was a flourishing black market patronized by the wealthier section of the population. Conditions were worse in winter than in summer when supplies of locally grown vegetables were brought to the city markets.

The milk supply had diminished to a fraction of the normal. Many cattle had been delivered to neighbouring countries under the Peace Treaty, others had been slaughtered for food and for 2 years after the armistice the small supply of milk in the city was officially reserved for infants, children's institutions and hospitals. Even in 1922, after 3 years of efforts at reconstruction, no free sale of milk for the general public was permitted in the city.

\section{Nutritional Diseases Frequent among Children and Adults}

The general impression made by the population as seen in the streets of Vienna in the autumn of 1919, twelve months after the armistice, was of great depression matched by slow fatigued movements, and pallid yellow faces. Rarely did one meet a child or grown person with a healthy or rosy complexion. It is not possible in the time at my disposal to deal with all the nutritional diseases encountered and only the most frequent will be described.

\section{Rickets and Osteomalacia}

As might be expected the young children and adolescents suffered most severely. Infants in many cases had been reared on cereal gruels with a minimum of milk. Rickets was almost universal among the young children and was often of a very severe degree, causing stunting of growth and gross deformities.

Late rickets among adolescents between the ages of 12 and 20 also was common, and hunger osteomalacia, which first made its appearance in the winter of 1918-19, was frequent among those classes of adults which by reason of poverty or other circumstances were unable to obtain a share of the unrationed food available. These included the old and elderly among the poorest section of the population, men and women alike, who were unable to obtain paid employment. In the convents, owing to both poverty and conditions of isolation, the lack of food was so extreme that the younger occupants suffered as severely as the older ones.

There was no evidence of association of this osteomalacia with pregnancy among women. Most women of child bearing age belonged to the younger age groups of the class of artisans and manual labourers, and these were among the better paid section of the population and could secure a more abundant supply of food.

\section{Scurvy}

Rickets among infants and young children was often accompanied by scurvy, which frequently occurred in epidemic proportions in children's institutions in the spring of the year. Its aetiology was often unrecog. nized by the medical profession although it was known as Barlow's disease (pronounced "Barloff", as the name was thought to indicate a Russian nationality for its discoverer). It occurred mainly among artificially fed infants and appeared to be caused by too high a proportion of 
cereal food in the diet and too low a proportion of fresh milk. In many cases, the repeated heating of milk which, owing to the slowness of transport, was necessary to keep it fresh until consumption, appeared to be responsible. It was not the custom to give any extra antiscorbutic material to infants nor indeed were any suitable materials available. The occurrence of scurvy appeared to be as important as of rickets in causing the severe check to growth and development which was so noticeable. It was not unusual to find children of normal weight at birth, who in their first 2 years had suffered from more than one attack of scurvy, and at this age were about half the normal weight, could neither sit nor stand without support, made no attempt at speech and gave little sign of awakened intelligence. Skin disorders and furunculosis were common in such children.

\section{Tuberculosis}

Tuberculosis, another disease which may be regarded as connected with malnutrition, showed a great increase in the eity during the war years. The mortality was increased by about 100 per cent. in 1918 and 1919, as compared with 1913 . In this respect there is a marked contrast between the records for the city and those for the provinces. In the province of Salzburg, which was relatively well fed, the increase was only about 15 per cent. Conditions other than food, including medical care and supervision, would be better in the city and these had not altered significantly during the war years, but the mortality from tuberculosis was doubled.

\section{Methods of Food Relief Adopted}

After the Armistice, import of food into Austria was controlled by an official British Food Mission which functioned for about 2 years, but the needs of the population were only very partially met.

The food shortage for the children of Austria was relieved chiefly by the American Relief Association, organized under the direction of Mr. Herbert Hoover, who at that time was Director General of the Inter-Allied Food Commission and a member of the Supreme Economic Council. When the U.S.A. Mission to Austria arrived in May, 1919, its expressed aim was to provide food for 60,000 undernourished children until the harvest of that year should be available. Medical examination of Austrian children carried out during the summer and autumn of 1919 , however, disclosed the fact that 75 per cent. of the 1,182,000 children in Austria, and 96 per cent. of the 340,000 in Vienna; were to some degree undernourished and in need of extra food. The original programme was, therefore, continually enlarged and extended until, in the spring of 1921, 400,000 children, chiefly of school age, were being fed daily. After this date the numbers needing relief steadily declined.

The children were selected after medical examination in accordance with criteria laid down by Professor Clemens v. Pirquet, Director of the University Kinderklinik. These were based partly on the clinical state of the skin and musculature, but chiefly on the value of a certain ratio between bodyweight and sitting height (length of head and trunk) which, according to his theories, gives a more useful indication of nutritional voL. 3,1945 ] 
state than values for height and weight considered separately. For a normally nourished child the value of the expression $\frac{\sqrt[3]{10 \times \text { weight in } \mathrm{g}}}{\text { sitting height in } \mathrm{cm} .}$ (the cube root of 10 times the weight in g., divided by the sitting height in $\mathrm{cm}$.), known as the "Pelidisi," should lie between 0.95 and 1.00 . Values below 0.94 were considered to indicate undernourishment and the need of extra food. During these examinations it was revealed that the average Viennese boy of 15 to 18 years old was 5 to $10 \mathrm{~cm}$. shorter, and 4 to $12 \mathrm{~kg}$. lighter, than the average English boy of similar age.

The organization of the relief was entrusted to Professor v. Pirquet who, with his assistant physicians, Drs. E. Mayerhofer and E. Nobel controlled an Austrian staff of some thousands, many of whom were specially trained for the work as the undertaking grew. By April 1921, 147,000 Vienna children between the ages of 3 and 18 were receiving a daily hot meal which provided 660 Calories for those under 14 years and 1000 Calories for those older. It was cooked in 27 large kitchens and carried in iron containers by motor lorries to feeding centres arranged in the public schools, kindergartens, orphan asylums and other institutions.

The foods used were chiefly imported from the United States, and included cocoa, tinned milk, beans, lard, bacon, sugar, rice and flour. There was an effective control, not only of the foods received and issued, but also of the calorie value of the meal served. In the arrangement of the menus the aim was to provide the required calories from carbohydrate, protein and fat. No attention was paid to vitamins, for knowledge of the recent developments of the science of nutrition had not penetrated to Central Europe during the preceding years of war and, with few exceptions, the members of the medical profession were either ignorant or incredulous.

The Relief Mission in Vienna of the Society of Friends, both British and American, endeavoured to fill the gaps left by the American Relief Administration. Its efforts included the feeding in their own homes of about 58,000 children under 6 years, the provision of clothing, of pensions for old people and of assistance of all kinds to the middle class families of professional men, students and officials, who were among the most impoverished of the population owing to the inflation of the currency. 'The Professors' messes provided by the American Relief Administration at the Universities of Vienna, Graz and Innsbruck, and the meals for students in their Mensas also brought great relief to these classes.

In addition, the Friends' Mission undertook work of a more constructive nature than simple relief. Successful attempts were made to increase local agricultural production and in particular to build up the diminished milk supply. Imports were arranged of cows, bulls and goats, with the necessary fodder concentrates for their maintenance. These animals were distributed on contract to farmers, municipalities, hospitals, and so forth, their value being gradually repaid in milk supplied to children's institutions or distributed by the Mission to the children under its care.

Among relief measures might be mentioned also the work of Professor v. Pirquet to combat tuberculosis among children. He arranged a sanatorium on the roof of his hospital to accommodate 150 children up to 14 years old. Here convalescent patients remained under treatment 
for relatively long periods and could continue their normal education. The "treatment" consisted mainly of insistence on adequate food intake and the atmosphere was rather that of a boarding school than of a hospital. It was a successful demonstration of an economic method for treatment of the tuberculosis which was then so prevalent among Austrian children.

\section{Opportunities Available for Nutritional Research}

It was evident that the nutritional diseases prevalent in Vienna at this period offered unusually favourable opportunities for research.

When with Dr. Elsie Dalyell of Sydney I went to Vienna in September, 1919 , the mission entrusted to us by the Lister Institute and the Medical Research Council was to study the aetiology of the deficiency diseases prevalent in that city, and to ascertain to what extent the recent discoveries of the effects of vitamin deficiencies in experimental animals were applicable to the human subject. In spite of our natural fears to the contrary, we obtained a very warm welcome, tempered with great scepticism for our theories, from the Austrian scientists and clinicians. Among the latter was Professor v. Pirquet who, although unconvinced by our views, was nevertheless anxious to collaborate in putting them to the test. He made us welcome in his clinic, treated us like honoured guests and offered fullest collaboration of himself and his staff in our researches.

Our Mission, which lasted about 3 years, was joined after a short interval by Miss E. M. Hume and later by Dr. Helen Mackay and Miss H. Henderson Smith.

\section{Scurvy}

Scurvy in infants and young children was prevalent, and most children's hospitals and infants' homes had suffered from outbreaks in the spring months of the last 2 years of war.

An outbreak had occurred in the University Kinderklinik in April 1919 which involved 40 of the 64 children from 6 to 14 years of age then undergoing sanatorium treatment for tuberculosis. In this Department there was unusually complete dietetic control and we were permitted to study the recorded food intake of the group for the 6 months previous to the outbreak. From these records we were able to show that the antiscorbutic material contained in the vegetables given should have been adequate for the prevention of scurvy had it not been for the excessive destruction of vitamin $\mathrm{C}$ taking place in cooking by the large scale methods adopted in the otherwise admirably run kitchen (Chick and Dalyell, 1920).

In the Landes Zentral Kinderheim which housed some hundreds of infants and young children, for which the State was responsible, scurvy had broken out with regularity each spring. With the collaboration of the physician in charge, Dr. M. Zarfl, we investigated the causes in this case also. Some of the babies were accompanied by their mothers and of the others most received some breast milk. There was also a fair amount of cow's milk available and all feeds were carefully, perhaps too carefully, prepared in a special milk kitchen. From a study of the operations it appeared that the milk was 3 or 4 days old when it was consumed in the wards and had been heated many times, often once before delivery at the Home in order to prevent the souring which would otherwise have occurred during slow and imperfect transport. The juice of voL. 3,1945$]$ 
oranges was unobtainable but a lorry load of swede turnips was procured and on our advice the raw expressed juice was given regularly with satisfactory results.

Some degree of rickets was almost universal among infants and this combined with an annual attack of scurvy prevented the normal development of the child to an extreme degree and produced the very backward children that are mentioned above (Chick and Dalyell, 1921).

\section{Hunger Osteomalacia}

In the summer of 1919 reports reached this country of the appearance in Vienna of a new disease, called adult rickets or osteomalacia, which companioned the almost universal occurrence of rickets in infants. Here then was a chance to study the aetiology of osteomalacia and to investigate the two conflicting theories regarding the cause of rickets which then were being hotly debated in our own medical and scientific circles. There was firstly the dietetic theory supported by the experimental work of Edward Mellanby and, secondly, the "environmental" theory of Paton and Findlay, emanating from the laboratories of this city of Glasgow. How the rival theories were eventually harmonized is a fascinating story now well known to everyone.

A characteristic feature of hunger osteomalacia was its occurrence in spring and disappearance during summer and autumn. This extremely painful and crippling condition was generally judged to be of nutritional origin and in its nature to bear some relation to rickets in children. The sufferers were chiefly elderly persons applying for relief at the offices of the Verband der Krankenkassen, a large sick benefit organization. Of 131 such cases studied by Hume and Nirenstein (1921), 81 (62 per cent.) were between the ages of 50 and 70 , and 49 ( 37 per cent.) between 60 and 70. The treatment previously adopted had been dosing with a vegetable oil containing phosphorus $(0.01 \mathrm{~g}$. P per $100 \mathrm{~g}$. oil) on the basis that the latter had a curative effect. Results were, however, disappointing and the only real improvement occurred with the advent of summer. At that date only one fat soluble vitamin had been differentiated, fat soluble $A$, of McCollum and his co-workers, and it seemed probable that the remission in summer was due to a better diet containing green vegetables. Controlled trials carried out by Hume and Nirenstein (1921) of the effect of "Phosphor OOl" and of cod liver oil showed the advantage of the latter.

It was significant that hunger osteomalacia was unusually severe in the enclosed convents, where both younger and older nuns were affected, and in many cases no improvement took place in summer; this was especially true where there was no garden or opportunity for outdoor exercise. In these communities food deprivation had been extreme, partly due to their isolated condition and partly to an antagonism then existing between the secular authorities and all Catholic institutions. With the co-operation of the Mother Superior, trials were made in an Ursuline Convent of supplementing the diet of different groups with selected foodstuffs. Extra calories in the form of sugar, olive oil, rice, or jam had relatively little effect, but animal fats, above all cod liver oil, worked swift cures. This result was confirmed on a series of severe bedridden cases admitted to the Allgemeines Krankenhaus. In some of these the effect of cod liver oil seemed miraculous (Dalyell and Chick, 1921). 


\section{Rickets}

The excellent opportunity offered for research on the aetiology of rickets in infants was recognized by the Medical Research Council and the Lister Institute, and the Mission was extended to permit of a somewhat elaborate investigation. In the University Kinderklinik, a study of the records showed that any infant or young child who remained in that hospital for periods of $\mathbf{6}$ months or over developed the disease to some degree in winter and spring in spite of excellent care and apparently satisfactory diet. Professor v. Pirquet was puzzled as to the cause, but was inclined to believe that the disorder was caused by an infection of low virulence whose course was influenced by the nutritional state and resembled that of tuberculosis in this respect. He was, however, anxious to collaborate in a carefully controlled test of the dietetic theory and for this purpose offered the hospitality of his clinic, the collaboration of himself and his medical and nursing staff, the well equipped X-ray department and all the advantages of the system of dietetic control operating in the hospital.

Accommodation was provided for between 40 and 50 young infants who were observed for periods of 5 to 15 months. On admission, they were allocated without selection to one of two groups which received, respectively, the milk and sugar diet usual in the clinic, and the diet prescribed by the British workers, of more milk and less sugar with cod liver oil in addition. All the children received a daily antiscorbutic in the form of the raw juice of swede, tomato or lemon.

The results were clear cut. The bones of the babies in the second group developed normally, those of the babies on the hospital diet showed a slight degree of rickets, diagnosed by $\mathrm{X}$-ray examination, in late winter and early spring. This, however, healed spontaneously when the weather became warm and the children, according to custom, spent many hours daily out of doors.

Studies were made also of cases admitted with severe rickets, all of which received the hospital diet. Those who were exposed to sunshine or to ultraviolet rays from an artificial source showed swift calcification of their epiphyses; the same was true of those who remained indoors and were dosed with cod liver oil. In absence of any of these 3 forms of treatment, no improvement could be detected radiographically even after long periods in the hospital (Chick, Dalyell, Hume, Mackay, Smith and Wimberger, 1922; Medical Research Council, 1923).

The explanation of the similar clinical effects of sunshine and of ad. ministration of the preformed vitamin $\mathbf{D}$ in cod liver oil was only made evident later as a result of the numerous investigations which were carried out in Europe and the United States during the following years.

\section{Conditions which May be Anticipated in Occupied Europe after the Present War}

As far as can be judged from the information available, the conditions of food shortage in Europe when the present fighting ceases will be different from those obtaining in Germany and Austria after the previous war. The food deprivation will have been more widespread, more severe, and not confined mainly to certain types of food. Semi-starvation may be expected among the poorer and more vulnerable classes of the ror. 3,1945 ] 
population and it is known that there has been a large spread of tuberculosis and increase in the proportion of deaths.

No report has reached us yet of hunger osteomalacia or of any widespread occurrence of severe rickets among children. Although the diets may be lacking in natural sources of vitamin $D$ such as eggs and butter, this vitamin can be manufactured cheaply in these days and, if combined with a moderate intake of phosphates and lime salts from bread and vegetables, should prevent any serious degree of these bone diseases. Sunshine also is cheap and can be enjoyed in spite of war conditions.

Similarly it is unlikely that there has been severe or prolonged deprivation of vitamin $\mathrm{C}$. It is certain that in the cities the winter and spring supplies of locally grown vegetables have diminished owing to the deportation of the labour needed for their cultivation. We also have evidence of the wholesale removal of potatoes by the occupying power. But synthetic ascorbic acid is not an expensive product and no doubt has been widely distributed. Further, knowledge is now universally available for using vegetable supplies to the best advantage, and for avoiding destruction of the vitamin by faulty methods of cooking.

Severe deprivation of vitamin $\mathrm{A}$ is more probable. Fats have been, and are, extremely scarce, and milk supplies are reported to have dwindled seriously owing to slaughter and deportation of milk cattle, so that for the vast majority the only source of vitamin $A$ will be the carotene in vegetable tissues. This suffers the disadvantage of much lower availability than preformed vitamin A. One can be sure that any cod liver oil produced in Norway or Sweden will have been reserved for the inhabitants of Germany. The world supplies of vitamin A are believed to be insufficient for the demands which will be made and equitable distribution will be a difficult task.

The chief deficiency which is likely to be encountered in the occupied countries, Greece, Poland, Belgium, Franoe, Holland and possibly to a lesser degree in Denmark and Norway, is plain lack of food, food of any kind, to provide sufficient calories for the body's needs. The deaths from starvation in Greece have already provided a national calamity, and semistarvation, if not worse, may be expected in many of the occupied countries.

Hunger oedema appears to have been common in Belgium and France since the time of their occupation. Its occurrence was frequently described during 1941 and 1942 in the medical press of these countries and, though latterly unmentioned, must assuredly be still present. Hunger oedema was reported in Germany during the last war as occurring in certain separated communities, e.g., in a labour corps attached to the German army in the winter 1916-17 (Schittenhelm and Schlecht, 1919). It was also frequent among young children in Poland, but outbreaks were not very common in the general population of the Central Powers. The disorder, however, received careful study and was considered due chiefly to protein starvation, although lack of total calories and of fats have usually preceded outbreaks. The sufferers showed a severe degree of emaciation when the oedema had subsided after treatment in hospital, so that the occurrence of the disease may be looked upon as evidence of some degree of starvation at least (see also Nixon, 1920).

It is likely that the grim opportunity will present itself for a study of the processes of slow starvation in the human subject and of the best methods to prevent the sudden and tragic collapse and death which, according to 
recent reports emanating from Bengal and from secret sources in prison camps in Europe, often occur after food has been given.

One problem which may well confront any investigators of nutritional disease in post-war Europe will be the difficulty of including controls in any trials. This is an ethical difficulty which crops up frequently in scientific investigation involving human subjects. Where suffering is acute and relief is at hand, the dilemma is intensified. Cures and not studies are demanded. In our experiences in Vienna after the last war the situation was different. Controls were only too abundant and we were regarded, possibly with some suspicion, as experimenters who were foolish enough to study the effect of additions to diets which local scientific and medical opinion regarded as qualitatively adequate. This being so, our trials were controlled in an unusually perfect manner and we were enabled to obtain a vindication of our theories which proved convincing to the most sceptical.

\section{References}

Chick, H. and Dalyell, E. J. (1920). Brit. med. J. ii, 546.

Chick, F. and Dalyell, E. J. (1921). Brit. med. J. ii, 1061.

Chick, H., Dalyell, E. J., Hume, E. M., Mackay, H. M. M., Smith, H. H. and Wimberger, H. (1922). Lancet, 203, 7.

Dalyell, E. J. and Chick, H. (1921). Lancet, 201, 842.

Hume, E. M. and Nirenstein, E. (1921). Lancet, 201, 849.

Medical Research Council (1923). Spec. Rep. Ser, med. Res. Coun., Lond., no. 77. Nixon, J. A. (1920). Bristol med.-chir. J. 37, 137.

Schittenhelm, A. and Schlecht, H. (1919). Die Odemkrankheit. Berlin: Julius Springer.

\section{Discussion}

Mr. J. G. Heathcote (Famine Relief Committee, Ayr): People are dying now in thousands in the occupied countries. Eighteen thousand have died in Athens of starvation alone. It will not be a case of worrying about specific details of the diet, it will be a case of getting food over in quantity. The position of hunger oedema is quite bad enough, but tuberculosis is even worse. An increased amount of transport should be available after the war, and the medical profession must view with alarm the possible spread of tuberculosis. I do not wish to raise any political issues or to call for political action on the matter, but feel that far more could be done, at the present time, to help those called upon to fight in our defence. Much is being done by such bodies as the International Red Cross, but they could do more; something is being done in Greece, on a limited scale, already, and that scale of relief has been increased lately, since the Government has been stirred on learning that, in the Argentine, they were burning wheat as fuel, while it is denied to our Allies in occupied Europe.

Dr. E. C. Owen (Hannah Dairy Research Institute, Kirkhill, Ayr): I have read in The Lancet of Dr. Chick's work. I should like to know what was the explanation for feeding the people phosphorus in oil for osteomalacia. Was it liquid yellow phosphorus dissolved in oil, or does it mean phosphorus only?

Dr. Chick gave the following reply:

To Dr. Owen: I believe it was phosphorus in minute amount dissolved in oil, but I have no real explanation to give. Even when giving cod liver oil they put phosphorus in it to help the bones.

vot. 3,1945$]$ 


\section{Poland's Agricultural Requirements in the Post-War Period}

Professor T. M. Olbrycht (Polish Committee of Medical-Veterinary Study, Royal (Dick) Veterinary College, Edinburgh)

\section{Introduction}

I would first like to thank you for giving me this opportunity of discussing the problems of the restoration of agriculture in Poland after the war. Before coming to these problems it should be pointed out that Polish agricultural conditions differ greatly from those in this country.

The pre-war population of Poland was 35 millions, of which on the average 64.9 per cent. derived their livelihood directly from agriculture, with a variation from 45 per cent. in west Poland to 95 per cent. in east Poland.

Compared with pre-war Britain, where only $5 \cdot 2$ per cent. of the active population was engaged in agriculture, Poland was an over-populated agricultural country with small, undeveloped industries. With few exceptions the soil is light and sandy and poor in humus, and requires heavy applications of mineral and green crop manures. Large scale grain production is unprofitable owing to the quality of the soil and the density of the agricultural population. A much greater return could be obtained from cattle and pig breeding, but only in the last few years before the war was much attention paid to this type of farming.

In Poland mixed farming was prevalent. Very few farms specialized in any one direction, e.g., pig production, dairy cattle breeding, poultry keeping, or glasshouse industry, as is the case in this country. The economic position of the Polish farmer depended entirely on the sale of his farm products, and there were no people with independent incomes farming only for a hobby as may happen in this country.

Of the total arable land $76 \cdot 3$ per cent. belonged to peasants, who owned the land themselves, in contrast with the tenant system in this country. There was, however, a small percentage of tenants on manor farms in Poland. A high percentage of peasant farms were small holdings under 12 acres, mostly under 5 acres, and not large enough to feed a family. Very typical of Poland was the small number ( 10.5 per cent.) of medium sized farms of 25 to 123 acres, which in Britain, Denmark and Holland form the greatest percentage of farm units. Especially in south Poland the farms were very small; there, 50 per cent. of the holdings were less than 5 acres in size, and about 30 per cent. of the cultivated area was taken up by a few very large estates and a great number of manor farms.

While in this country there is a scarcity of farm labourers, in Poland there was a great surplus of agricultural workers. The density of distribution of farm workers in Poland was very high compared with Britain. In Poland there were on an average 31 farm workers to every 240 acres of farm land. In some parts there were as many as 80 workers to every 240 acres, while in Britain there are only 15 farm workers to every 240 acres of farm land. Of a total of 20 million active Polish farm workers, over 2 million were superfluous in agriculture, but owing to lack of industry they could not be absorbed in the towns. 
The superfluous farm labourers with their families made up about 5 million landless proletariat on the land, and, being unable to transfer into industry, they caused over-crowding of the villages with a constant increase of population. The peasant farms have decreased in size steadily from generation to generation owing to new divisions of the land by inheritance and marriage; each holding consisted of small patches of ground, and the land round the villages looked like a chessboard of small fields, difficult to cultivate. It was rather like the system of agriculture prevailing in England in the 14th century, when the land was divided into small strips and the peasants had strips in different parts of the fields.

Steady shrinking of peasant farms, over-population of the villages, and hunger for land caused an abnormal rise of land values and, with a simultaneous fall in the prices of agricultural products, were the cause of great poverty. The peasant had to sell everything he produced in order to discharge his obligations, without leaving enough food for his family; and so, in a country which exported yearly 13,000 tons of butter, 266,000 head of pigs, 21,000 tons of bacon, 17,000 tons of hams, 29,000 tons of eggs, 20,000 tons of meat, 85,000 tons of sugar, 238,000 tons of barley and many other food products, the villages, especially in south Poland, had a shortage of bread before the harvest, and no milk for the children; there was general malnutrition, a high rate of infant mortality, and a high percentage of young men unfit for military service. These bad conditions have become even worse during the present war, as we shall see later.

The restoration of agriculture in Poland after the war will depend on 4 factors:

1. On supplying Poland with livestock, seed, mineral fertilizers, machinery, implements, fuel and rolling stock destroyed during the war or transferred to Germany.

2. On restoring normal conditions in the chaos which the present disturbed circumstances have caused in agrarian relations, through deportation of people, expropriation, and German settlement on farms taken from the Poles.

3. On the restoration of the production of those types of crops and animals which will be most important for feeding the people and most profitable for the farmers. The Germans have made various changes in production according to the requirements of their army, e.g., instead of breeding bacon pigs the Polish farmer has to produce German pork pigs; instead of sugar beet he has to grow oil seeds.

4. On improving the efficiency of the farming system through changes in economic organization.

To solve the first problem, Polish agriculture needs help from outside; the second, third and fourth must be solved by the Poles themselves. Without such a solution, the restoration and further development of agriculture would be impossible.

\section{Help Needed from Outside}

I shall deal here only with the first problem, namely, with the scale of destruction of agricultural livestock, machinery, implements and so forth during the war, and the necessary supplies which must be obtained from outside of animals, seeds and fertilizers. I shall deal also with the voL. 3, 1945] 
methods which must be introduced immediately after the war to protect domestic animals from contagious diseases and to improve the utility qualities of the breeds, since animal husbandry is in Poland the most important part of agriculture, not only to supply the population with the most important food, but also from the economic point of view.

The requirements of Polish agriculture can be estimated from the fall in production during the war, and from the decrease in the number of farm animals, implements and fertilizers, in comparison with pre-war years.

The present agricultural situation in Poland has been ascertained from various German publications, German agricultural radio announcements and from Polish underground organizations. The data were collected and submitted to the Allied Post-War Requirements Bureau.

In Poland there are 3 different economic spheres under German occupation, differing in the amount of devastation they have suffered:

l. Annexed territories incorporated directly into the Reich. Here, in spite of changes in husbandry, production has been maintained or even slightly increased.

2. The General Government or central and south parts of Poland. Exploitation has been more drastic here and agricultural losses are up to 50 per cent.

3. The eastern territories of Poland. Here the devastation has been much greater and vast areas have been destroyed and left uncultivated. The number of livestock in some parts of east Poland has fallen by as much as 90 per cent., while the remainder is often hidden in the forests to escape German punitive expeditions.

\section{Cattle}

The decrease in numbers since the war is given in Table 1.

TABLE 1

Changes in Cattle Population Caused by the War

(thousands)

\begin{tabular}{|c|c|c|c|c|}
\hline \multirow[b]{2}{*}{ Territory } & \multicolumn{2}{|c|}{ Number } & \multicolumn{2}{|c|}{ Decrease } \\
\hline & 1938 & 1943 & Number & $\begin{array}{l}\text { Per cent. of } \\
1938 \text { figure }\end{array}$ \\
\hline $\begin{array}{l}\text { Annexed to the Reich } \\
\text { General Government } \\
\text { East Poland .. }\end{array}$ & $\begin{array}{l}2648 \\
3208 \\
4698\end{array}$ & $\begin{array}{l}2383 \\
2246 \\
1879\end{array}$ & $\begin{array}{r}265 \\
962 \\
2819\end{array}$ & $\begin{array}{l}10 \\
30 \\
60\end{array}$ \\
\hline Total & 10554 & 6508 & 4046 & 41 \\
\hline
\end{tabular}

The post-war requirements of cattle are as follows: About 2000 good, pure bred bulls may be expected to be found in Poland after the war, but 5000 will have to be imported to use with the best 350,000 breeding cows which should be expected to be still in Poland. Of the 5000 bulls about 4000 should be of Friesian, 800 of Simmental and 200 of Red Silesian breeds. To produce our own pure bred bulls it would be necessary to 
import also about 500 pure bred heifers. To solve the problem of feeding children in the first period after the war the import of more than 1 million utility cows will be required for milk production apart from breeding.

Before the war Poland had about 6,800,000 milch cows and now there are only about 4 million left.

\section{Pigs}

The number of pigs in annexed territories has remained about the same as before the war, and German Improved Landrace boars are used for lard production. In 1943, the decrease in pigs in the General Government was; according to data from the German press, 33 to 44 per cent. in relation to pre-war numbers, and in east Poland the number of pigs decreased by more than 80 per cent. in many districts, but in others the situation is better and an estimated decrease of about 60 per cent. is probably correct for the whole of eastern Poland.

The present number of pigs in Poland can be calculated from the decrease in the number of pigs in 1943 in the General Government and east Poland, by adding to this figure the number of pigs in 1938 in the annexed territories (Table 2).

TABLE 2

Changes in Pig Population Caused by the War

(thousands)

\begin{tabular}{|c|c|c|}
\hline \multirow[b]{2}{*}{ Territory } & \multicolumn{2}{|c|}{ Number } \\
\hline & 1938 & 1943 \\
\hline $\begin{array}{l}\text { Annexed to the Reich } \\
\text { General Government } \\
\text { East Poland }\end{array}$ & $\begin{array}{l}2395 \\
1986 \\
3144\end{array}$ & $\begin{array}{l}2395 \\
1291 \\
1258\end{array}$ \\
\hline Total & 7525 & 4944 \\
\hline
\end{tabular}

There should be a sufficient number of boars of the lard type in the annexed territories and in East Prussia to supply central and eastern Poland. West and south Poland will probably return to bacon production and will require importation of about 2000 Large White boars to grade up the native stock and, besides homebred sows, also about 100 Large White sows from Great Britain in order to breed the necessary pure bred Large White boars after the relief period. No Middle White breed would be required, because in west Poland pork pigs are now brought in sufficient numbers from Germany; besides, the production of porkers of 100 to $140 \mathrm{lb}$. liveweight is a luxury trade, and was never practised in Poland.

I mention this because in the official statement of Polish pig requirements are included 100 Middle White boars. This breed is unnecessary for Polish purposes and it would be difficult to find so many pure bred Middle White boars, as only 34 entries were made in the herd book of the National Pig Breeders' Association in 1941.

vor. 3,1945 ] 
Horses

The position is summarized in Table 3 .

TABLE 3

Changes in Horse Population Caused by the War (thousands)

\begin{tabular}{|c|c|c|c|c|}
\hline \multirow[b]{2}{*}{ Territory } & \multicolumn{2}{|c|}{ Number } & \multicolumn{2}{|c|}{ Decrease } \\
\hline & 1938 & 1943 & Number & $\begin{array}{l}\text { Per cent. of } \\
1938 \text { figure }\end{array}$ \\
\hline $\begin{array}{l}\text { Annexed to the Reich } \\
\text { General Government } \\
\text { Eastern Poland .. }\end{array}$ & $\begin{array}{r}951 \\
1069 \\
1896\end{array}$ & $\begin{array}{l}903 \\
748 \\
758\end{array}$ & $\begin{array}{r}48 \\
321 \\
1138\end{array}$ & $\begin{array}{r}5 \\
30 \\
60\end{array}$ \\
\hline Total & 3916 & 2409 & 1507 & 38 \\
\hline
\end{tabular}

To improve horse breeding it would be desirable to import about 700 of medium draft type. The best results before the war were achieved by grading up Polish mares with stallions imported from Sweden and Norway. Also about 300 mares of the same type would be required to produce pure bred draft breeding stock, acclimatized to Polish conditions.

The importation of light types, and especially of thoroughbred stallions, is regarded as superfluous for agriculture. The shortage of utility horses could be made up from the demobilized German army.

Sheep

The number of sheep in the whole of Poland has been reduced from $3,411,000$ to $1,888,000$, but the decrease is only in the General Government and eastern Poland, while in the annexed territories the number of sheep has increased by about 25 per cent., i.e., from 480,000 before the war to about 600,000 in 1943.

Foreign sheep which could be used to improve Polish sheep breeding are: Kent,Hampshire,Border Leicester,Merino-précoce,Rumanian and Karakul. Feeding Stuffs

In the first period of relief there will be a shortage of feeding stuffs, especially of protein rich concentrates. Roughages will probably be produced in sufficient quantity in Poland. If hostilities cease in summer there will be grass in abundance for feeding dairy cattle.

The most important concentrates which will be needed are: wheat bran and oilcakes, chiefly used for feeding dairy cattle in Poland; barley meal for feeding pigs; oats for horses.

The reconstruction of old and the building of new factories for the production of meat meal, bone meal and fish meal would help in the feeding of animals.

\section{Veterinary Supplies for the Relief Period}

The immediate eradication of contagious diseases of animals in Poland after the war is of great importance not only for Poland but for all other countries of western and central Europe. These western countries would be readily contaminated if infections were not effectively controlled in Poland. Such a danger did exist after the last war, when cattle plague 
(pestis bovina) spread. Up to 1923, when the plague was exterminated, 12 Polish provinces had been infected; 7318 cattle died, 6483 were killed and there were only 1851 recoveries. It was the immediate control and production of serum in the Polish institute at Pulawy that enabled this devastating disease to be wiped out, and so removed any danger of its westerly spread. The disease was much feared by specialists in Germany, Denmark, France, and other countries, and several veterinary surgeons came from these countries to Poland to see and study the symptoms and methods of eradication of a disease that was fortunately unknown to them.

To meet the not less serious conditions which will almost certainly prevail after this war, we propose the following scheme and recommendations.

1. To build 32 sanitary control stations at the Polish borders for inspection of all animals crossing the frontiers, with accommodation for necessary quarantine. These to be distributed as follows: 15 on the east border, 8 on the west, 6 on the south, and 3 on the north (at ports).

2. To restore the 10 testing stations (veterinary laboratories) which were established in Poland for the examination of suspected cases of disease, equipped with apparatus, microscopes, bacteriological supplies and reagents sufficient for the first 2 months for all 10 stations.

3. To establish 34 mobile units consisting of about 175 well equipped cars to assist the district veterinarians in the eradication of infections.

4. To restore at least one serological institute, with the necessary equipment.

5. To supply vaccines and sera during the first 2 months, before this institute is able to produce them.

6. To obtain chemicals for disinfection of buildings and fixed structures, as well as for personnel and their vehicles, sufficient for the whole country, for the first 2 months.

7. To obtain curative drugs, injections and hormone preparations sufficient for 2 months.

8. To restore and build up to 34 permanent animal clinics for the poor. These clinics will require chemicals, drugs and other equipment.

9. To obtain equipment for slaughterhouse laboratories in towns having 20,000 or more inhabitants. There are 71 such towns.

A great part of the original equipment of the veterinary institutions existing or which existed in Poland has been destroyed during the war or has been transferred to Germany. It seems therefore reasonable to expect that some or all of the material required for restoring and improving the Polish veterinary services after the war should be demanded from the enemy as a condition of peace, not only for the purpose of securing reparation and a measure of justice, but also for the practical and necessary purpose of ensuring the safety of western Europe from contagious animal diseases that may originate in the east in the present disturbed circumstances and in those conditions which may be expected to arise as soon as hostilities cease.

\section{Rapid Improvement of Quality of Domestic Animals by Artificial Insemination}

It will probably be impossible to supply Poland with such a large number of male breeding stock as has been enumerated above; it is voL. 3,1945 ] 
essential, therefore, to introduce on a big scale artificial insemination. We are already making preparations for this purpose, and a course in Cambridge was organized last year to train veterinary surgeons in methods of artificial insemination, and now periodically 2 or 3 Polish veterinary surgeons are sent to Cambridge for a few months to study the procedure, and students of veterinary science are given lectures on this subject at the Royal (Dick) Veterinary College, Edinburgh.

To safeguard the future of the herds in Poland an organized system of artificial insemination will be required. The low standard of literacy of the Polish peasantry, including most of the owners of cattle, and the economic depression which will mean concentration on a subsistence minimum during the period of recovery, will make state organization to guard against disease and sterility a necessity. A plan has been prepared by which the collection, importation and distribution of semen will be controlled by the Ministry of Agriculture, the Polish Zootechnical Society, and the Veterinary Colleges. There will be a central station in Warsaw and distribution will be through local stations under chambers of agriculture, other local bodies, including breeders, co-operatives, and veterinary surgeons. The veterinary colleges would undertake the training of specialist officers.

\section{Seeds}

According to the Report of the Seeds Sub-Committee, Allied Post-War Requirements Bureau, there is a further serious decrease in cultivated land in central and eastern Poland because of the considerable area which has lain fallow. The occupying authorities pressed the Polish farmers to increase production of crops, but owing to exhaustion of the soil, lack of fertilizers and of livestock, the general level of yield for the whole of Poland is below the pre-war average. For example, the production of oil seeds in the annexed territories increased by about 5 per cent., but for the whole of Poland the production of oil seeds declined by about 15 per cent., with the exception of rape seed, which shows an increase of about 58 per cent.

Table 4 gives the production of crops in Poland before the war and approximate yields in 1943 .

TABLE 4

Approximate Crop Yields

(thousand metric tons)

\begin{tabular}{|c|c|c|c|c|c|c|}
\hline \multirow[b]{2}{*}{ Crop } & \multicolumn{3}{|c|}{ Gross harvest } & \multicolumn{3}{|c|}{ Analysis of 1943 harvest } \\
\hline & $\begin{array}{l}\text { Average } \\
1935-37\end{array}$ & 1943 & $\begin{array}{c}\text { Decrease } \\
\text { or increase } \\
\text { per cent. }\end{array}$ & Seed & Waste & $\begin{array}{c}\text { Net } \\
\text { harvest }\end{array}$ \\
\hline $\begin{array}{l}\text { Wheat . . } \\
\text { Rye } \quad . \\
\text { Barley .. } \\
\text { Oats } \\
\text { Linseed } \\
\text { Rape seed } \\
\text { Hemp seed }\end{array}$ & $\begin{array}{l}2023 \\
6106 \\
1411 \\
2526 \\
72 \cdot 3 \\
49 \cdot 6 \\
19 \cdot 5\end{array}$ & $\begin{array}{c}1215 \\
5190 \\
930 \\
1895 \\
54 \cdot 8 \\
78 \cdot 4 \\
15\end{array}$ & $\begin{array}{l}-40 \\
-15 \\
-35 \\
-25 \\
-24 \\
+58 \\
-22\end{array}$ & $\begin{array}{l}225 \\
930 \\
163 \\
340 \\
14 \cdot 16 \\
1 \cdot 67 \\
2 \cdot 1\end{array}$ & $\begin{array}{c}60 \cdot 7 \\
259 \cdot 5 \\
46 \cdot 5 \\
94 \cdot 4 \\
2 \cdot 74 \\
3 \cdot 9 \cdot 2 \\
0 \cdot 7\end{array}$ & $\begin{array}{c}930 \\
3941 \\
720 \\
1461 \\
37 \cdot 9 \\
72 \cdot 8 \\
12 \cdot 2\end{array}$ \\
\hline
\end{tabular}


The requirements of seeds are summarized in Tables 5 and 6 .

TABLE 5

Estimated Requirements of Seeds for Crops for Human Consumption (metric tons)

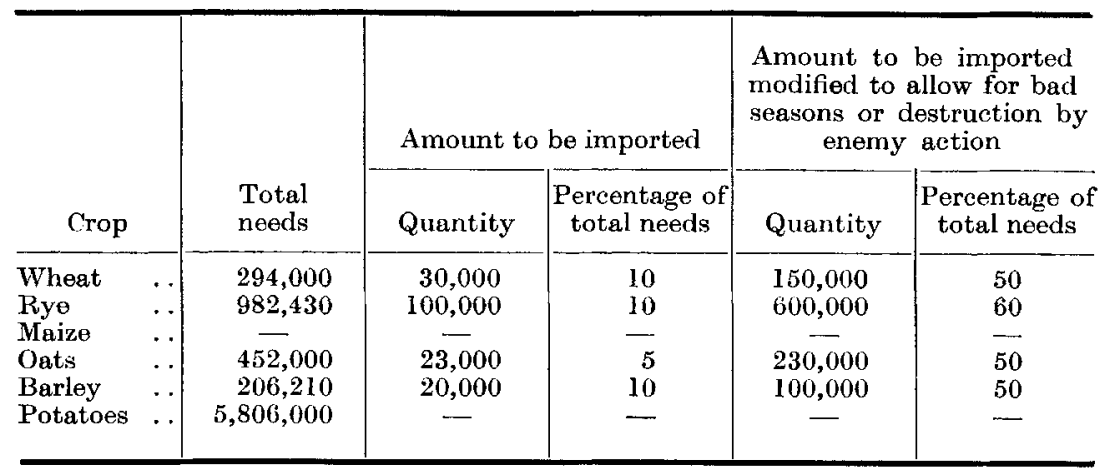

Seed import requirements depend on the general food and fodder situation. There would be sufficient seed from the domestic crop if normal imports of cereals for food and fodder were available, but imported seed would be required for farms liberated from the Germans and for regions which have had bad crops. The supplies of oats and barley seed from home crops depend also on the imports of wheat and rye for food.

TABLE 6

Estimated Requirements of Seeds for Crops Matnly for Animal Consumption (metric tons)

\begin{tabular}{|c|c|c|c|c|c|}
\hline \multirow[b]{2}{*}{ Crop } & & \multirow[b]{2}{*}{$\begin{array}{l}\text { Total } \\
\text { needs }\end{array}$} & \multicolumn{2}{|c|}{ Amount to be imported } & \multirow[b]{2}{*}{ Source } \\
\hline & & & Quantity & $\begin{array}{c}\text { Percentage of } \\
\text { total needs }\end{array}$ & \\
\hline $\begin{array}{l}\text { Sugar beet } \\
\text { Fodder roots }\end{array}$ & $\begin{array}{l}\text {. } \\
\text {. }\end{array}$ & $\begin{array}{l}2560 \\
3720\end{array}$ & 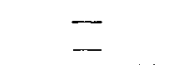 & - & \\
\hline Clover $\quad \cdots$ & . & 15,000 & $\begin{array}{lr}\text { Red } & 3000 \\
\text { White } & 500\end{array}$ & 25 & $\begin{array}{l}\text { Germany, Denmark, } \\
\text { U.S.A. }\end{array}$ \\
\hline $\begin{array}{ll}\text { Lucerne } & \ldots \\
\text { Grass } & \ldots\end{array}$ & . & - & - & - & \\
\hline Peas & . & 27,900 & 3000 & 10 & $\begin{array}{l}\text { Germany, Czecho- } \\
\text { slovakia }\end{array}$ \\
\hline Beans & . & 15,450 & 1500 & 10 & $\begin{array}{l}\text { Rumania, Czecho- } \\
\text { slovakia, Germany }\end{array}$ \\
\hline $\begin{array}{l}\text { Lupin } \\
\text { Serradella }\end{array}$ & $\begin{array}{l}\cdots \\
\cdots\end{array}$ & $\begin{array}{l}75,000 \\
10,000\end{array}$ & $\begin{array}{r}25,000 \\
3000\end{array}$ & $\begin{array}{l}33 \\
30\end{array}$ & \\
\hline
\end{tabular}

\section{Fertilizers}

The post-war requirements for nitrogenous and phosphatic fertilizers as given by the Polish Committee are set out in Table 7. Potash fertilizers can be supplied from home production.

voc. 3,1945 ] 
TABLE 7

Requirements of Fertilizers to be Imported

(metric tons)

\begin{tabular}{|c|c|c|c|}
\hline Fertilizer & & $\begin{array}{l}\text { Winter } \\
\text { delivery }\end{array}$ & $\begin{array}{c}\text { Spring or summer } \\
\text { delivery }\end{array}$ \\
\hline $\begin{array}{l}\text { Nitrogenous } \\
\text { Calcium cyanamide } \\
\text { Nitro-chalk } \ldots \\
\text { Sulphate of ammonia }\end{array}$ & \begin{tabular}{l|}
$\cdots$ \\
$\cdots$ \\
$\cdots$
\end{tabular} & $\begin{array}{l}16,000 \\
48,000 \\
16,000\end{array}$ & $\begin{array}{l}40,000 \\
24,000 \\
16,000\end{array}$ \\
\hline $\begin{array}{l}\text { Phosphatic } \\
\text { Superphosphate } \\
\text { Basic slag .. }\end{array}$ & $\begin{array}{l}\cdots \\
\cdots\end{array}$ & \multicolumn{2}{|c|}{$\begin{array}{l}100,000 \\
100,000\end{array}$} \\
\hline
\end{tabular}

Agricultural Machinery, Implements and Fuel

To cultivate the vast fallow areas it will be necessary to equip about 540 tractor columns with 16,000 tractors, about 23,000 ploughs, and 11,000 harrows. There will also be a lack of cultivators, rollers, planting machines, diggers, threshers, and so forth, and of rolling stock with fuel and lubricants.

The importation in the first year after the war of horse and hand power implements such as drills, reapers, mowers, dressing drum sorters and scythes, and of steel for spades, shovels, forks and hoes will be essential to restore crop production and feed the starved population.

In conclusion I must point out that in the requirements given I have not included replacement of farm buildings bombed and burned through military action, e.g., stables, cow sheds, barns, granaries.

The reconstruction and development of Polish agriculture in the postwar period is dependent also upon the re-establishment of agricultural schools and experimental stations. The requirements for this purpose are not mentioned in this paper.

\section{The Hot Springs Conference and its Bearing on the Development of Agriculture}

Sir E. John Russell (Campsfield Wood, nr. Woodstock, Oxon.)

The Hot Springs Conference may well prove to be one of the turning points in the history of the world. The representatives of forty-four nations agreed that large numbers of people on the earth have insufficient food and that, in consequence, there is much avoidable ill health and inefficiency; and they stated their intention that better nutrition should henceforth be the aim of their governments. This, they recognized, would involve a large output of the protective foods, but they pointed out that the production of these foods would raise the standard of farming and so widen the benefits resulting from better nutrition.

Before the war two different types of agriculture were practised in Europe.

In the United Kingdom we started with the idea that each country should produce the things it could do best and should then exchange its 
surplus with other countries with the minimum of cost and formality. This was the free trade doctrine of the nineteenth contury and it gave us cheaper and more abundant food than we had ever had before. In its pure form the doctrine required unhampered liberty of action by the producer and unrestricted competition. This in the end led to highly undesirable results. Our farmers could not compete in grain production with those of North America, and had to change their type of farming. But there was much groping in the dark and many men were practically ruined during the process. In North America the need for lowering costs of production, and the desire to make money while it was still possible, encouraged systems of farming that led straight to soil erosion, with the result that many farmers were ruined and their soils were destroyed. The old free trade, laissez faire, system therefore proved unworkable in practice.

But many valuable lessons were learned during this period and it was soon realized that the cause of the trouble had been the complete lack of organization and of control in the interests of the community. The fundamental idea that each region should produce what it was suited to produce, and exchange its products, was not called in question. It did appear, however, that the production should be organized, that the methods must not be destructive of the soil, and that the organization should be in the interests of the community and not of a particular group of individuals.

The effect on our agriculture was to reduce greatly the production of wheat and to curtail heavily the acreage of arable land. This fell continuously from the peak of 1872 right up to 1939 , excepting only for a brief upward spurt in the last war. The area of grass land increased and with it the number of cattle. Milk production increased. The numbers of sheep, however, fell till new methods came in about 20 years ago, when they started to rise.

The numbers of workers fell also, but a remarkable and quite unexpected result was the increased value of output per worker, and so it was possible to pay the better wages demanded by the men. Poultry and egg production and fruit and vegetable production increased also and also permitted of rising value of output per man. Not only the workers but the soil benefited, for the yield of arable crops steadily rose. Only the yield of hay went down.

The general conditions of life in Great Britain gave us a rich and varied dietary, but one requiring for its production much more land than we had got, so that we could not have produced it all ourselves. Our agriculture gave us before the war the whole of our milk and potatoes, almost all our bulky green vegetables, more than two-thirds of our poultry and eggs, almost half our meat, one-third of our sugar and cheese, but only one-quarter of our wheat and one-tenth of our butter. These, with the balances of the other foods, had to be imported, necessitating the use of much shipping and a big export trade to pay for the products. On the whole we produced about thirty-five or forty per cent. of our food and imported sixty or sixty-five per cent.

On the Continent of Europe, especially in Germany and Italy, an entirely different agricultural policy was adopted. Each country, it was claimed, should be self sufficing, at least for all staple foods. The policy

vor. 3,1945 ] 
was carried out with great skill in Germany. A dietary was developed that was physiologically adequate but much less attractive than ours; it required, however, much less land for its production than ours. Some eighty-five per cent. of self sufficiency was therefore attained against our thirty-five or forty per cent. On the agrioultural side the system necessitated concentration on grain and potatoes, it did not permit of the high value of output per worker attained here, nor was the value rising; in consequence the standard of life for the countryman was lower.

The Hot Springs resolutions would not involve a great change in the type of farming in Great Britain, though they would call for intensification of production and extension of some of the new industries begun before the war, e.g., fruit preserving and canning and drying of vegetables. Nor would the agriculture of Denmark and Holland be much affected as their systems were already orientated in this direction.

But the agriculture of central and eastern Europe would be considerably affected, because the Hot Springs resolutions are not compatible with the policy of self sufficiency, and their adoption would involve a shift over from grain and potato production to more livestock, eggs, poultry, fruit and vegetables. This would affect the peasants in several ways. Considerable eapital charges would be incurred for the new equipment, seeds, fertilizers, feedingstuffs and other things needed. Much technical education would be required. Illiteracy, which ranges from nearly 70 per cent. downwards, would have to cease.

Another change affects the pattern of country life. The new methods could be practised on either large or small farms; our experience shows that they are quite suitable for small farms. But on the Continent the large farmers, with their superior resources, could change over much more quickly than the peasants and sell their products to better advantage. So far as our information goes, however, the peoples of Europe all prefer the small farm to the large one, and are prepared to make whatever arrangements are needed to help the small man. Chief of these are the provision of the necessary capital and of the technical education and advice, and the development of co-operative organizations without which it would be almost impossible for the small producer to stand up to competition. This all implies more education and wider education, not merely technical but general, and not merely factual but moral.

The old policy of self sufficiency meant a low standard of living for both townsman and countryman; the policy of high nutrition offers the possibility of higher standards for both, and of continually rising standards for the countryman.

\section{Discussion}

One of the audience asked what standard of nutrition could the whole world have if the produce of the land were arranged according to the principles outlined at the Hot Springs Conference.

Sir John Russell replied: We have not got enough information about most of the world to answer that question, not even in regard to Europe. One can only say that a considerable improvement is possible in all production. The present system of agriculture in Europe is not directed to the production of the best diet but to meet the policy of self sufficiency. 
How far a compromise could be effected we have not yet got the information to say.

One of the audience asked how the world could support large scale farming if, as indicated, the output from a 250 acre farm was relatively greater than that from a 2500 acre farm.

Sir John Russell replied: I have emphasized the fact in this talk that such figures must not be taken as being generally valid. They illustrate the risk that, from the large farm you do not get the same output as from the small farm. From the whole of the land, however, you could get a higher output. You might not get overall an output of the same kind as from the small farm. The man who is working on his own land puts his back more into the work, for instance, looking after animals. The animals understand an individual master better than a sequence-of workers just as a dog understands one owner, and so any domestic animal is better to be looked after by one person. The unit of optimum result is necessarily rather small. Take the average dairy herd in this country, about 14 cows, and roughly what one man can adequately supervise.

Dr. G. Dunlop (Auchincruive, Ayr): The small farm represented in the talk was an arable farm where you would tend to get a high output, while the large farms cited might include hill country, where sheep grazing is common, and a high output as from arable land would not be expected. There are very good data from Russia to show the increased production obtained under the collective farm system compared with the system of small peasant farms.

Sir John Russell replied: As I said, in Russia the peasants work on small holdings. It is found that the income from the collective farms is 11 times what it is from the small holdings on which the peasant spends one-third of his labour; that is, he may work for 200 days for a collective farm and will work for 100 days on his small holding, but that does not account for the 11 times difference.

Dr. G. Dunlop: There was another point that arose in the talk. In some places the peasant farms are so small that mechanized methods are impossible and the peasants are forced to work on teaspoon-and-shovel methods. It takes 1.6 acres to provide enough food per individual, and nothing is left over to buy the other necessities of life. The co-operative farming in Palestine appears to be ideal.

Sir John Russell replied: This trend is general and is the same in any group of data that one takes. I gave it as a tendency only. In Russia, after permission was given for the peasants to have their own little holding, it was found that there was more livestock in the hands of the peasants than on the collective farms. When it comes to livestock, the individual has the advantage.

Dr. G. Dunlop: What are Professor Olbrycht's views?

Professor Olbrycht replied: I do not know what the questioner specially wants to know. I think the production of grain does not pay in parts of Europe, and therefore it is necessary to confine farming to animal production, as is done in Poland, Denmark and Switzerland. There they have family farms and the animals receive detailed care. The farmer must supervise everything himself in the dairy and pigsty. Livestock voL. 3, 1945] 
must be tended from morning to night, but you do not require to watch the grain fields. For Russia it is very easy to make big collective farms because there is no over-population, but in Poland we do not know what to do with all the people. In fact, fewer workers are needed on the land.

Dr. L. G. D. Muir (Glasgow): It appears from what has been said that small farms are necessary merely to keep more people employed. It is a terrible admission of defeat that we cannot devise measures to direct the population to other forms of production. A technical side should be devised by UNRRA and industry linked up with agriculture. Is there any such co-ordination in UNRRA under consideration?

Sir John Russell replied: It is known that a country cannot live by agriculture alone, for, if it is sufficiently prosperous, the agricultural population begins to multiply and the Malthusian theory applies. Regarding the direction of population, emigration is no longer possible, but there have been considerable advances in the linking up of industrial with agricultural life. For instance, there has been considerable development of minerals and oils. Czechoslovakia has done better than any other country. They have well established industries in which they have had considerable success and prosperity, especially glass and engineering. The vitally important thing is, however, to screw up the output from the land as hard as one possible can.

Mr. J. Fleming (Tighnabruaich School, Argyllshire): The chief producing countries, South America, New Zealand and Australia, all with sparse populations, have big farms with comparative prosperity and a big export trade. The smaller southern European countries have dense populations, small farms and less prosperity. The figures Sir John gave do not seem to tally with this. In my opinion the only way to tackle the question is nationally as has been done in the U.S.S.R.

Sir John Russell replied: South America is very largely ranch, and the production per acre is extremely small. Land is less valuable, and density of population is extremely low. In New Zealand conditions are very different and in Australia we have large scale stock farming, which is the usual practice where dense population is impossible. Where the physical conditions are such that you can have a dense population on the land, you tend to get small farms. Water is one of the main problems involved.

Miss M. Andross (College of Domestic Science, Park Drive, Glasgow): Difficulties are experienced in Ayrshire where the agricultural workers do not want to go to the farms in outlying districts, so that these farms have to become mechanized. Are the corresponding people in Europe more backward and content to stay in outlying districts than the country people here, where more and more people are reaching out for the attractions of the towns? Would our people be content to work on co-operative farms?

Sir John Russell replied: In Europe there was no alternative. Here, there is an alternative. In any country where there is a large preponderance of peasants, there still survives a love of the land, and a desire to own a piece of it. So long as that survives, there will be no difficulty in getting people to live on the land. With small farms the question of remoteness does not arise because the neighbours live closer together. 
Dr. D. Snow (Hannah Dairy Research Institute, Kirkhill, Ayr): How far can this country take the responsibility for the re-organization of European agriculture, and how far must it be left to individual governments to work out their own salvation? In the case of Poland, Professor Olbrycht has said we could send them seeds, stock, implements, and machinery, but other important points would have to be left to their own working out, for example, land tenure. I feel that this country should take a responsibility beyond merely sending basic equipment. Sending machinery, for instance, will change the type of farming. I think too that we have to bring to our own people the point of view that we must live at a very much reduced level of imports. Sir John mentioned the dairy industry of Denmark, with butter a chief export. In general, nutritional diseases had dropped, but not in Denmark. And what about UNRRA and the difference between friendly countries and belligerent countries? All goods going to belligerent countries must be paid for. It is very doubtful whether belligerent countries can pay for them, and I think all scientists should express very clearly that there should be no distinction between sending food to friendly or belligerent countries. How does the production of cereals in Europe fit in with a better food policy?

Sir John Russell replied: I will deal with this last question only, the other statements showing political implications outwith my lecture. How does the production of cereals fit in with a better food policy? Not very much. It will be necessary for Europe to import considerable amounts of cereals, and for that we require peace and the re-establishment of international trade in order that these can be paid for. So long as there is a risk of war, countries will aim at self sufficiency. This country is about 40 per cent. self sufficient, but in European countries the proportion goes up to 70 per cent. 